\title{
Tendencies of medical education researches in Turkey: Content analysis of 2000-2014 period
}

\author{
Türkiye'de tıp eğitimi araştırmalarındaki eğilimler: 2000-2014 döneminin içerik analizi
}

Kürşat Volkan ÖZCAN, İdris GÖKSU, Sevda KÜÇÜK, Yüksel GÖKTAŞ

\begin{abstract}
Objectives: The aim of this study is to reveal the tendencies of the researches on the medical education in Turkey in terms of the instruction levels that the researches took place, methodological dimensions and instructional activities conducted in the researches.

Materials and Methods: The sample of the study was composed of researches published in medical journals indexed in ULAKBIM National Database and in PubMed Database between 2000 and 2014. Within this context, the total number of papers was 214. These papers were examined through Medical Education Publication Classification Form (MEPCF) conducting content analysis.

Results: As for the results, the participants of most of the studies were the students who were about to graduate. It was observed in the researches that quantitative research method was used most; questionnaires were the most used data collection tool; and instructional activities related to curriculum development and evaluation were used frequently.
\end{abstract}

Conclusion: The results are considered to help the researchers see the trends and tendencies in medical education and assess the field of medical education from different perspectives.

Keywords: Medical education, Research trends, Content analysis

Kürşat Volkan Özcan (汹)

Department of Medical Education, School of Medicine, Gaziosmanpaşa University, Tokat, Turkey

e-mail:kursatvolkan@hotmail.com

İdris Göksu

Department of Computer Programming, Midyat Vocational High School, Mardin Artuklu University, Mardin, Turkey

Sevda Küçük, Yüksel Göktaş

Department of Computer Education and Education Tehnologies, School of

Education, Atatürk University, Erzurum, Turkey

Submitted/Gönderilme: 17.05.2015 Accepted/Kabul: 31.08.2015

\section{ÖZET}

Amaç: Bu araştırmanın amacı, Türkiye'de tıp eğitimiyle ilgili yapılmış çalışmaları; çalışmaların yapıldığı öğretim basamakları, yöntemsel boyutları ve çalışmalarda uygulanan öğretimsel faaliyetler açısından inceleyerek araştırmalardaki eğilimleri ortaya koymaktır.

Gereç ve Yöntem: Araştırmanın örneklemini 2000-2014 yılları arasında yayınlanmış ULAKBİM ulusal veri tabanında dizinlenen tıp bilimleri dergileri ile PubMed veri tabanı tarafından taranan uluslararası yabancı dergilerde yayınlanmış Türkiye adresli çalışmalar oluşturmaktadır. Bukapsamda 214 makaleye ulaşılmıştır. Çalışmalar Tıp Eğitimi Yayın Sınıflandırma Formu (TEYSF)'na göre incelenmiştir. Araştırmada içerik analiz yöntemi kullanılmıştır.

Bulgular: Sonuçlara göre çalışmalar en çok mezuniyet öncesi öğretim basamağında gerçekleştirilmiştir. İncelenen çalışmalarda yaygın olarak nicel araştırma yönteminin uygulandığı, veri toplama aracı olarak genellikle anketlerden yararlanıldığı ve program geliştirme ve değerlendirme konulu öğretimsel faaliyetlerin sıklıkla tercih edildiği görülmüştür.

Sonuç: Elde edilen sonuçların tıp eğitimindeki eğilimlerin görülmesine, araştırmacıların farklı açılardan tıp eğitimi alanını değerlendirmesine yardımcı olacağı düşünülmektedir.

Anahtar kelimeler: Tıp eğitimi, Araştırma eğilimleri, İçerik analizi

\section{Introduction}

The effort to train doctors who help people stay healthy brings about different approaches over time. This effort is also the chief aim of medical education [1]. In the science of medicine having 5000-year history, recent radical changes and different opinions about how the medical education should be arouses interest $[2,3]$. The beginning of the use of technology in educational settings has given a new impulse to medical education [4].Moreover, some modifications are made in educational systems, duration of the training and 
curriculum in order to offer contemporary approaches to patients and equip doctors with up-to-date knowledge[5]. These modifications and searches can be considered as an effort to train more qualified doctors. The notion of training doctors in accordance with the needs of the country requires the problems about medical education to be solved. This requirement increases the importance of researches on medical education [6].

There are different implementations about medical education both in Turkey and in the world. Although the duration and structure show variety depending on the country, medical education is usually composed of three stages; pregraduate, post-graduate and continuing education[7].The education given in the faculties in bachelor degree is called pre-graduate medical education. The aim of pre-graduate education is to train and equip the students who study at faculties and would be general practitioners after graduation so that they could meet the needs of public [8]. It also has three stages; pre-clinical, clinical and transition to the career [9]. In post-graduate education, it is aimed to provide education of evidence-based medicine, ethics, patient rights and health policies, which could help candidate specialist physicians offer an effective health service, and studies for this goal are conducted $[10,11]$. It can be stated that it is important for general practitioners and specialist physicians to be aware of novel developments, especially today with rapid changes in medicine. In continuing education, educational activities especially including sharing of new developments and experiences are organized, and it is known that physicians show great interest in these activities [12].Here, it may be necessary to differentiate between postgraduate education and continuing education. Post-graduate education provides opportunity to get an academic degree. However, in continuing education, the purpose is to gain new knowledge and skills [13].

Beside the differences in duration and structure of education, the roles of teachers and learners are changing[14]. As a result of these differences and the development in educational sciences, it can be expressed that education models in medical education vary. Moreover, in order for the changes to be successful, there are some factors such as characteristics of students and the field where the changes are applied that should be considered in addition to the accuracy of the model [15]. The foundation of new medical faculties and the fact that these faculties determine their teaching applications by imitation or trial-error make it difficult to reach the targeted learning outputs [5].The changes in medical education can be revealed by researches investigating this process. Therefore, it is important to track the researches in medical education and the results of these researches. Such studies can be seen in literature [15].

When the studies about medical education is examined, the study of Dimitroff and Davis (2006) is remarkable. Examining the articles published between 1975 and 1994, the authors state that 773 out of 3689 papers are about the medical education [16]. It is emphasized as a result of the study that the most studied instructional activities are curriculum evaluation and student assessment. It is also stated that observations, tests and questionnaires are commonly used data collection tools [16]. In a similar study published in 2004, it is stated that although there are different studies on medical education, the dominant instructional activities are curriculum development, individual characteristics of students, and assessment and evaluation[17]. Besides, Lifshitz (1997) expresses that the most commonly studied instructional activities are learning characteristics of adults, the importance of individual differences, and new educational techniques [18]. In another study examining the researches on medical education which published between 1988-2011 in Europe and USA, it is observed that the most commonly studied instructional activities are assessment and evaluation, communication skills, and problem-based learning[19].

Although there are studies aiming at determining the tendencies in the field of medical education in a variety of countries, the authors of this study couldn't find any study examining the tendency in medical education in Turkey. Therefore, it is considered that revealing the tendencies of researches conducted in Turkey by examining them in terms of form and content will contribute to the field. Furthermore, the multi-dimensional examination of the researches will contribute to the researchers in medical education. This study aims at revealing the general tendencies and descriptive and methodological dimensions of medical education researches that could be accessed through international journals in PubMed database until 2015 and medical journals indexed in ULAKBİM national database.

\section{Material and Methods}

With the aim of determining the tendency in the field of medical education, studies between 2000 and 2014 in Turkey were analyzed in terms of content. In content analysis, studies or texts are summarized and categorized in accordance with some rules, and this technique allows repeatable objective implications [20].This approach was 
used in order to analyze the studies deeply and to examine the data in categories within the scope of this study.Content analysis is also used to describe a situation as it was in the past or as it is currently [21]. The technique of content analysis makes it possible to interpret the numbers which are obtained by transforming the data[22]. Within this context, content analysis was used within the aims of the study in compliance with the relevant literature $[16,17,19]$.

\section{The Scope of the Study}

The scope of the study is composed of researches on medical education in Turkey between 2000 and 2014. Within this context, this study involves medical education researches conducted in Turkey and published in international journals in PubMed database and medical journals indexed in ULAKBIM national database until 2015. The following questions are tried to be answered:

1) Which instructional levels do the researches involve and what is the yearly distribution of these researches?

2) What is the distribution of researches on medical education by the field of application?

3) In researches on medical education;

a) Which methods are widely used?

b) Which data collection tools are widely used?

c) Which data analysis techniques are widely used?

4) What is the distribution of the themes investigated in researches on medical education?

5) Which variables (subjects) are investigated in researches on medical education?

\section{Data Collection}

The search and selection criteria were specified by the authors to determine the researches to be involved in this study. Within this context, the journals within the scope of this study and the researches on medical education in these journals were determined. The search was conducted in ULAKBIM national database and PubMed database by using "tıp eğitimi" and "medical education" as keywords, and the relevant researches were accessed. Differently from ULAKBIM, the search on PubMed was conducted by selecting Turkey in the location filter. The search was also conducted in the journals' issues in the past 15 years separately in case there could be other researches than the ones available in ULAKBIM. Thus, the content validity of the study was tried to be ensured.

In order for the studies accessed during the search to be involved in this study, they were required to be conducted in at least one of three stages; pre-graduate, post-graduate, and continuing education. Moreover, studies investigating problems and themes such as assessment and evaluation, curriculum development, individual differences in learning, technology-assisted education, etc. were included in the study. The data collection process can be seen in Figure 1.As a result of the search, 255 studies were accessed, but 41 of them weren't within the scope of this study.

The yearly distribution of journals and researches examined in this study is presented in Table I. The studies obtained were recorded on Medical Education Publication Classification Form (MEPCF) which was designed in parallel with the research question by utilizing the Educational Technologies Publication Classification Form [23]. The data were recorded electronically after the studies were examined by three authors separately with the aim of ensuring the reliability and internal validity. The data recorded by the authors were compared, and those that had differences were examined again to ensure the internal validity.

\section{Data Analysis}

214 studies related to medical education were examined in terms of publication type, instructional level, field of application (department), method, data collection tool, data analysis method, and instructional activities. The studies examined were recorded on MEPCF, and the MEPCFs were transformed into tables by a computation table software. The data obtained were analyzed using descriptive statistical techniques (percentage, frequency). The data are presented in tables and graphs in findings section in accordance with the research questions.

\section{Results}

\section{Instructional Levels of the Studies and Their Yearly Distribution}

When the studies on medical education was examined, it was observed that the majority of the researches were conducted in pre-graduate level $(\mathrm{n}=139)$. It was followed by postgraduate $(n=53)$ and continuing education $(n=48)$. It was also observed that the number of studies conducted in the last 7 years $(n=140)$ was nearly twice as high as the number of studies in the first 8 years $(n=74)$. The distribution of studies in terms of instructional levels can be seen in Figure I. Lastly, an increase in all instructional levels in recent years was determined. 
Table I. Journals consisting more than one study and yearly distribution of studies

\begin{tabular}{|c|c|c|c|c|c|c|c|c|c|c|c|c|c|c|c|c|}
\hline Journal Title & 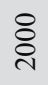 & Бे & ฮิ & 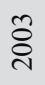 & ষ্ণ & $\stackrel{\overbrace{}}{\check{c}}$ & 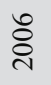 & $\hat{\text { ¿ }}$ & $\stackrel{\infty}{\stackrel{ి}{\circ}}$ & 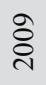 & $\stackrel{\circ}{\circ}$ & $\overline{\widetilde{N}}$ & $\stackrel{\text { ก }}{\frac{1}{2}}$ & $\stackrel{m}{\frac{n}{2}}$ & 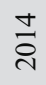 & 要 \\
\hline Advances in Physiology Education & & & & 1 & & & & 1 & 1 & & 2 & 4 & 1 & 1 & & 11 \\
\hline Medical Teacher & & & & 1 & 1 & 1 & 3 & 1 & 1 & 2 & & & & & & 10 \\
\hline Education for Health & & & & & & 1 & 1 & & 4 & & 2 & & & 1 & & 9 \\
\hline BMC Medical Education & & & 1 & & 1 & 1 & & & & 1 & 2 & & & & 1 & 7 \\
\hline Marmara Medical Journal & & & & & & & & 1 & & & 2 & 1 & & & 3 & 7 \\
\hline Bulletin of Microbiology & & & & & & 2 & 2 & & & & & & & & 2 & 6 \\
\hline Gulhane Medical Journal & & & & 1 & & & & & & & 1 & 1 & & 2 & & 5 \\
\hline Medical Education Online & & & & & & & 1 & & 1 & & & & & 1 & 2 & 5 \\
\hline Continuing Medical Education & & & & & & & & 1 & & 1 & & & 1 & 1 & 1 & 5 \\
\hline $\begin{array}{l}\text { Teaching and Learning in Medicine: An } \\
\text { International Journal }\end{array}$ & & & 1 & & 1 & 2 & & & 1 & & & & & & & 5 \\
\hline $\begin{array}{l}\text { Journal of Dokuz Eylül University Medical } \\
\text { School }\end{array}$ & & & & & & & 1 & 1 & & & & 1 & 1 & & & 4 \\
\hline Pamukkale Medical Journal & & & & & & & & & 1 & & & 1 & & & 2 & 4 \\
\hline Balkan Medical Journal & & & & & & & 1 & & & 2 & & 1 & & & & 4 \\
\hline Advances in Health Sciences Education & & & & & & 1 & & & 1 & 1 & & & & & & 3 \\
\hline $\begin{array}{l}\text { The Journal of The Turkish Society of } \\
\text { Algology }\end{array}$ & & & & & & & 1 & & 1 & & & & & & 1 & 3 \\
\hline $\begin{array}{l}\text { The Journal of Academic Emergency } \\
\text { Medicine }\end{array}$ & & & & & & & & & & 1 & & & & 2 & & 3 \\
\hline Cumhuriyet Medical Journal & & & & & & & & & & 2 & & & & 1 & & 3 \\
\hline Erciyes Medical Journal & & & & & & & & 1 & & & & 1 & 1 & & & 3 \\
\hline European Journal of Clinical Pharmacology & & & & & 1 & 1 & & & & & & & & 1 & & 3 \\
\hline Journal of Pakistan Medical Association & & & & & & & & & & & & & 1 & & 2 & 3 \\
\hline Journal of Surgical Education & & & & & & & & & 1 & & & & 1 & 1 & & 3 \\
\hline Surgical and Radiologic Anatomy & & & & & & 1 & & & & & & 1 & & 1 & & 3 \\
\hline TAF Preventive Medicine Bulletin & & & & & & & & & & & 1 & 1 & 1 & & & 3 \\
\hline Uludağ Medical Journal & & & & 2 & & 1 & & & & & & & & & & 3 \\
\hline Croatian Medical Journal & & & & & & & & 1 & 1 & & & & & & & 2 \\
\hline Dicle Medical Journal & & & & & & & & & & 1 & & & 1 & & & 2 \\
\hline Ege Journal of Medicine & & & 1 & & & & & 1 & & & & & & & & 2 \\
\hline European Journal of Emergency Medicine & & & & & & & & & & 2 & & & & & & 2 \\
\hline European Journal of Internal Medicine & & & & & 1 & 1 & & & & & & & & & & 2 \\
\hline International Journal of Emergency Medicine & & & & & & & & & & & & & & 1 & 1 & 2 \\
\hline Journal of Cancer Education & & & & & 1 & & & & & & & & 1 & & & 2 \\
\hline Journal of Clinical and Analytical Medicine & & & & & & & & & & & & & & 2 & & 2 \\
\hline Journal of Palliative Medicine & & & & & & & & & & & & & & 1 & 1 & 2 \\
\hline Patient Education and Counseling & & & & & & & & & 1 & & & & 1 & & & 2 \\
\hline Psychiatry and Clinical Neurosciences & & & & & & & 2 & & & & & & & & & 2 \\
\hline $\begin{array}{l}\text { The Tohoku Journal of Experimental } \\
\text { Medicine }\end{array}$ & & & & & & 1 & 1 & & & & & & & & & 2 \\
\hline Tuberculosis and Thorax & & & & & & & 1 & & & & 1 & & & & & 2 \\
\hline
\end{tabular}




\begin{tabular}{|c|c|c|c|c|c|c|c|c|c|c|c|c|c|c|c|c|}
\hline Journals in which the Data Collected & હ్సે & હ્ڤ్ & ڤ్ & ڤ్ & ఫ్ & 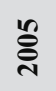 & 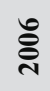 & ڤ్ & 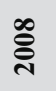 & ڤ్సે & 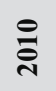 & $\bar{乛}$ & 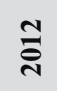 & $\stackrel{m}{\stackrel{n}{N}}$ & $\stackrel{ \pm}{\vec{\sim}}$ & 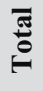 \\
\hline Turkish Journal of Geriatrics & & & & & & & & & 1 & & & & & 1 & & 2 \\
\hline Turkish Journal of Medical Sciences & & & & & & & 1 & & & & & 1 & & & & 2 \\
\hline Turkish Journal of Pathology & & & & & & & & & & & & 1 & & 1 & & 2 \\
\hline $\begin{array}{l}\text { The Turkish Journal of Thoracic and } \\
\text { Cardiovascular Surgery }\end{array}$ & & & & & & & & & & & & & 2 & & & 2 \\
\hline Turkish Journal of Psychiatry & & & & & & & & & & & 2 & & & & & 2 \\
\hline $\begin{array}{l}\text { Archieves of The Turkish Dermatology and } \\
\text { Venerology }\end{array}$ & & & & & & & & & & & & & & 1 & 1 & 2 \\
\hline Turkish Journal of Family Practice & & & & & & & & & & & & & & & 2 & 2 \\
\hline World Neurosurgery & & & & & & & & & & & 1 & & & 1 & & 2 \\
\hline Others & 1 & 1 & 2 & 5 & 1 & 4 & 7 & 3 & 3 & 4 & 3 & 5 & 3 & 7 & 8 & 57 \\
\hline TOTAL & 1 & 1 & 5 & 10 & 7 & 17 & 22 & 11 & 18 & 17 & 17 & 19 & 15 & 27 & 27 & \\
\hline
\end{tabular}

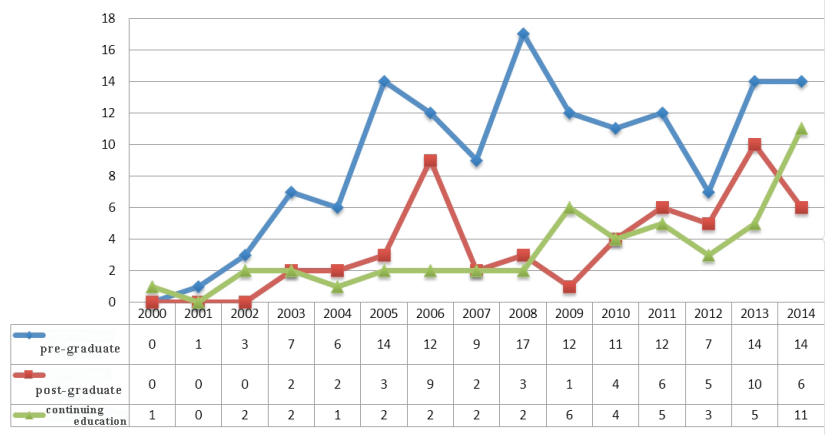

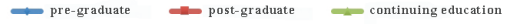

Figure I. Data collection process of the research
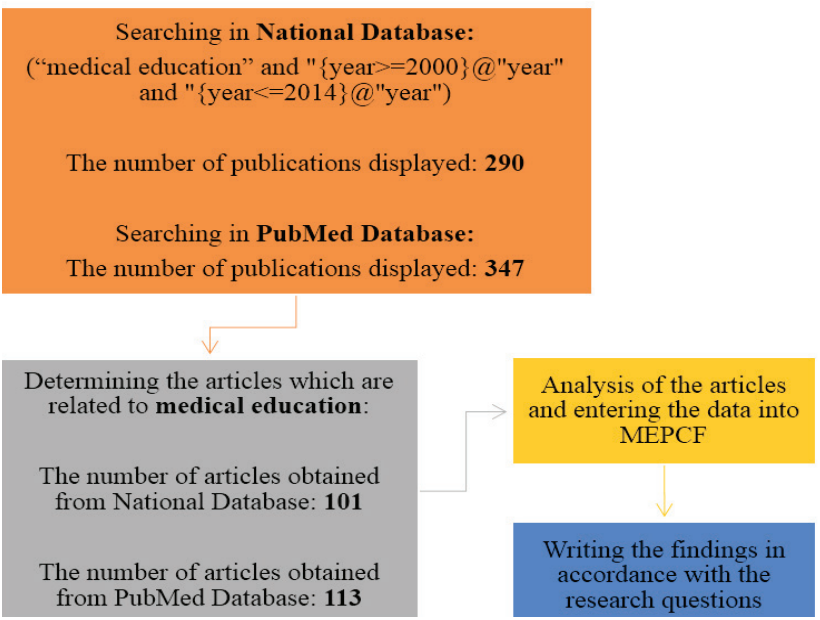

Figure II. Instructional levels focused on researches and their yearly distribution
The Distribution of Studies in terms of Field of Application

90 out of 214 studies were determined not to be classified into a specific department; instead, they were categorized as "Whole Faculty / General". Moreover, the most common fields of application were "Medical Education", "Emergency Medicine", "Pharmacology" and "Family Practice". No study involving "Histology and Embryology" and "Biostatistics" was found.

\section{In the Researches on Medical Education}

\section{Widely Used Research Methods}

169 out of 214 studies were determined to use quantitative methods. It was followed by literature review $(n=26)$, mixed $(\mathrm{n}=10)$ andqualitative $(\mathrm{n}=9)$. It was also determined that qualitative and mixed methods weren't used in the early years but were started to be used in the last 10 years.

\section{Widely Used Data Collection Tools}

When the widely used data collection tools and their yearly distribution were examined, it was observed that questionnaires $(\mathrm{n}=108)$, achievement tests with open-ended or multiple-choice questions $(\mathrm{n}=50)$ and attitude tests $(\mathrm{n}=24)$ were used usually. It was determined that the least used tools were observation and interview forms. These rarely used forms weren't utilized especially until recently. 


\section{Widely Used Data Analysis Methods}

When the data analysis methods of the studies and their yearly distribution were examined, it was observed that quantitative data analysis techniques were used more frequently than to qualitative ones.

It was seen that $46.73 \%$ of the studies preferred to use descriptive analysis, which is a quantitative method. The least frequently used analysis technique was determined to be descriptive analysis $(1,87 \%)$ which presents data clearly and remarkably and usually uses direct quotations. 201 out of 214 studies examined within this study used at least one data analysis method. The reason why this number is high is that more than one data analysis techniques were used in some studies examined.

\section{Widely Investigated Themes in Studies on Medical Education}

It was observed in the studies that the most commonly preferred instructional activities were curriculum development and evaluation $(\mathrm{n}=86)$, assessment and evaluation $(n=35)$ and instructional design $(n=35)$. Some of the studies focused on more than one instructional activities; therefore, it is normal for the total number of instructional activities to be higher than 214, which is the number of studies examined in this study. There are studies less in number that focused on individual differences in learning $(n=14)$ and technology-assisted education $(n=13)$. Moreover, it was observed that studies on technology-assisted learning and individual differences in learning were started to be conducted in the last ten years.

\section{Subjects of Medical Education Investigated in Medical Education Researches}

The distribution of variables investigated in researches within the scope of this study in terms of instructional levels is presented in Table II. The most commonly investigated variables were determined to be academic achievement $(\mathrm{n}=45)$, program competency $(\mathrm{n}=45)$, the effectiveness of education $(n=37)$, attitude $(n=35)$ and expectation $(n=32)$. The motive to prefer $(n=3)$, procedure skills $(n=3)$ and the number and profile of instructor $(\mathrm{n}=5)$ were among the least commonly investigated variables.

When Table II is examined in terms of instructional levels, it is seen that the number of studies investigating such variables as attitude and expectation in pre-graduate level are higher than post-graduate and continuing education levels.

Table II. Widely investigated medical education subjects and related problems

\begin{tabular}{|c|c|c|c|c|c|c|c|c|c|c|c|c|c|c|c|c|c|c|c|c|}
\hline $\begin{array}{c}\text { Instruct-ional } \\
\text { Level }\end{array}$ & 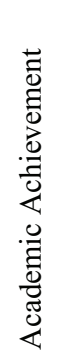 & 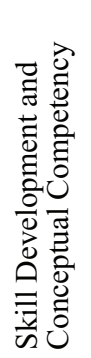 & 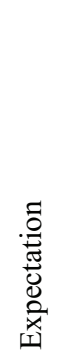 & 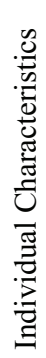 & 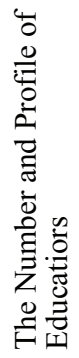 & 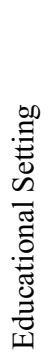 & 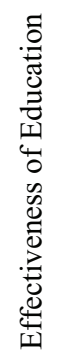 & 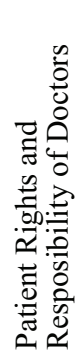 & $\begin{array}{l}\overline{8} \\
0 \\
0 \\
0 \\
0 \\
0 \\
0 \\
0 \\
0 \\
\tilde{\Xi}\end{array}$ & 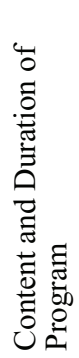 & 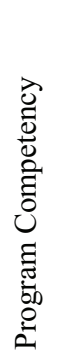 & 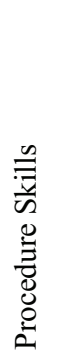 & 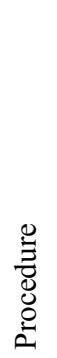 & 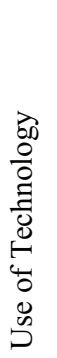 & 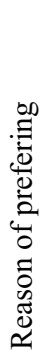 & 兽 & 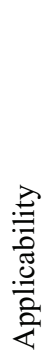 & 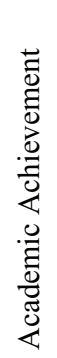 & 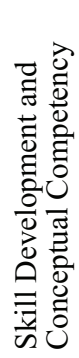 & 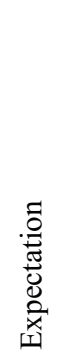 \\
\hline Pre-graduate & 24 & 2 & 23 & 8 & 1 & 8 & 23 & 5 & 7 & 3 & 30 & - & 6 & 4 & 2 & 21 & 7 & 30 & - & 6 \\
\hline Post- graduate & 11 & 5 & 8 & 1 & 4 & 7 & 4 & - & - & 2 & 12 & 1 & 4 & 2 & 1 & 4 & - & 12 & 1 & 4 \\
\hline $\begin{array}{l}\text { Continuing } \\
\text { education }\end{array}$ & 10 & 1 & 1 & - & - & - & 10 & 2 & - & - & 3 & 2 & 4 & 1 & - & 10 & 2 & 3 & 2 & 4 \\
\hline Total & 45 & 8 & 32 & 9 & 5 & 15 & 37 & 7 & 7 & 5 & 45 & 3 & 14 & 7 & 3 & 35 & 9 & 45 & 3 & 14 \\
\hline
\end{tabular}




\section{Discussion}

In this study, 214 researches conducted in Turkey and published in journals that indexed in PubMed and ULAKBIM databases between 2000-2014 were investigated in terms of instructional level, field of application, research method, data collection tool, data analysis method, and instructional activities and variables.

During the study, it was realized that the number of articles has increased considerably in the last five years. This situation may result from the fact that medical education departments in Turkey are relatively new. It is widely known that the number of studies focusing on medical education around the world has been increasing in recent years [24]. Medical Education Departments play an important role in the accreditation of medical education, and in recent years, postgraduate education has started to take place in these department. It can be stated that these advancements leads new researches to be conducted. When the researches were examined in terms of instructional level, it was determined that the highest number of articles was in the "pre-graduate" level, followed by "post-graduate" and "continuing education", respectively. As a matter of fact, it was also expressed in the literature that a higher number of articles are published in pre-graduate level than to post-graduate and continuing education [25]. It is stated that this situation results from the difference between teaching of courses in basic sciences and clinical sciences [25].It is known that assessments are conducted periodically in this instructional level since it is important to determine how well the content and goals are acquired. However, the lack of feedback from the trainings given within the scope of continuing education can be a reason why the number of studies focusing on this instructional level is so low [5].Another reason of the high number of studies focusing on pre-graduate level is the effort to give a comprehensive education despite the individual differences [25].Some researches on post-graduate level are known to be conducted with the aim of learning about the contemporary medicine literature [26].

When the articles were examined in terms of field of application, it was observed that the number of articles categorized as "Whole Faculty / General" were higher than the others. The need of a collaboration between different departments to teach new approaches and concepts in medical education has brought about a necessity to conduct studies especially not focusing on a single department [27]. The high number of studies conducted in pre-graduate education can be a reason of the high number of studies categorized as "Whole Faculty / General". Other widely preferred fields of application were "Medical Education", "Emergency Medicine", "Pharmacology" and "Family Practice". The active roles of departments of medical education in the integration of novelties in medicine and educational sciences into the medical curriculum may result in the high number of studies conducted in the field of Medical Education[5]. Studies of medical education in Emergency Medicine and Family Practice may be viewed as a result of standardization efforts of the education given in these fields[28, 29]. The relation of Family Practice with many branches may be a reason for preference in the publications about medical education.

When the studies were examined in terms of methods, it was observed that quantitative studies had the highest number, followed by review studies. The least preferred were mixed and qualitative methods. Indeed, it is stated in the literature that quantitative methods are more preferred in medical education researches [30].Easy data collection process and the generalizability of findings can be some of the reasons why quantitative method are preferred so much. However, qualitative methods have been stepping forward recently because they give more comprehensive and deeper results although quantitative methods have the ability to be generalizable [31,32].It can be stated that the use of mixed methods (using both quantitative and qualitative methods) can make it possible to reach more reliable findings.

When the data collection tools of the studies were examined, it was observed that the majority of studies used "questionnaires" and "achievement tests" while the "observation" and "interview form" were the least used tools. Similar results are easily found in the literature. Examining the data collection tools in studies focusing on problem-based teaching in Turkey, Tosun and Yaşar (2013) expressed that questionnaires and achievement tests were used frequently. However, in the same research, it was found that interview forms, questionnaires and achievement tests were used frequently in studies conducted abroad [33]. The majority of the studies examined in this research preferred quantitative methods; therefore, the widely use of questionnaires and achievement tests as data collection tool is normal.

It was determined that descriptive and predictive analysis, two techniques of quantitative methods, were used in the studies examined. However, the use of interview, questionnaire and observation form is expressed to be increasing because of the growing popularity of case studies as a research design in medical education researches [34]. The widely use of questionnaire and achievement tests may have required the descriptive or predictive analyses to be 
conducted in the researches frequently.

When the studies were examined in terms of instructional activity applied, it was observed that curriculum development and evaluation was conducted most. It was followed by assessment and evaluation, and instructional design, respectively. The low number of studies focusing on technology-assisted teaching and individual differences/ learning styles and strategies was remarkable. When the relevant literature is examined, it can be seen that technologyassisted teaching and assessment and evaluation were the most instructional activities in number [19]. Moreover, some studies show that curriculum development and technology-assisted teaching are applied today more than the past $[24,32,35]$. The high number of studies focusing on curriculum development may be the result of some reasons such as the differences in the conduction of lessons between basic sciences and clinical sciences, not completing of national core curriculum for years, and unclarity of curriculums [25, 36, 37]. Besides, there are some studies suggesting that studies focusing on the technology-assisted teaching are low in number because of the costs despite the development of technology and the limitations on the budget of the education [31].

The variables examined most were academic achievement, program competency and the effectiveness of education. In parallel with these findings, it was stated that such variables as program competency, academic achievement and attitude were frequently investigated[16]. The effort spent on curriculum design and standardization may explain the frequently use of program competency variable[38]. Moreover, there are studies stating that academic achievement and skills are investigated frequently [34]. Besides, it was observed that such professional competencies as patient rights and responsibility of the doctor weren't investigated in the post-graduate level and barely investigated in the continuing education level. It is stated in the literature that informing the patients about their rights are very rare and more studies about this situation should be conducted [39].

In conclusion, it can be said that this study is more comprehensive since it investigates some other variables such as instructional level and discipline where the applications conducted. The results of this study may help researchers see the tendency and weak parts of researches in medical education and guide them into researches about medical education. In the lights of the results of this study, the following suggestions can be made:

1. A limitation of this study is the absence of articles in the journals not indexed in national database. A more comprehensive investigation including the studies excluded in this research may help reveal the tendency more clearly.

2. After determining more experienced and successful countries in medical education, similarities and differences between these countries and Turkey can be investigated.

3. Medical education researches in post-graduate and continuing education levels can be encouraged. It is considered that continuing education activities can be enhanced by taking developments in medicine into consideration and these activities can be examined and evaluated. This would contribute to the field of medical education.

4. The actuality and effectiveness of teaching can be ensured by supporting the initiatives aiming at extension of field of application of medical education studies and encouraging multi-disciplinary studies.

5. The researchers in this field can be provided with information about the importance and effectiveness of mixed and qualitative research methods.

6. The quality of the studies can be raised by using different data collection or assessment tools.

7. Studies on "Individual Differences / Learning Styles and Strategies" and "Technology-Assisted Teaching" can be encouraged and a cooperation between medicine and education faculties can be supported.

8. Studies focusing on patient rights and responsibility of doctors, technology usage and personal development, lifelong learning skills in all of three instructional levels can provide an example in terms of spreading such factors of curriculum and investigation of their educational effects.

9. Departments of medical education can be founded in all of the medicine faculties; post-graduate programs can be founded in more faculties; some planning about increasing the number of academicians in this field can be made; and lastly, academicians studying on this field can be encouraged.

\section{References}

1. Sayek İ, OdabaşıO. Türk Tabipleri Birliği mezuniyet öncesi tıp eğitimi raporu 2010. http://www.ttb.org.tr/kutuphane/ mote_2010.pdf (Accessed on 14 July, 2015)

2. Özçakır A. Tıp eğitiminde değişim rüzgârları ve probleme dayalı tıp eğitiminden bir örnek: Maastricht Üniversitesi/ Hollanda. T KlinJ Med Sci 2001; 21: 324-4.

3. Çırakoğlu B. Türkiye'de tıp eğitiminin geleceği. TÜBİTAK 
Vizyon 20232001, http://www.tubitak.gov.tr/tubitak_content_ files/vizyon2023/si/EK-23.pdf (Accessed on 14 July 2015)

4. Bradley P. The history of simulation in medical education and possible future directions. Med Edu 2006; 40: 254-7. doi: 10.1111/j.1365-2929.2006.02394.x

5. Goudar SS, Kotur P F. Trends in medical education. Indian J Anaesth 2003; 47: 25-4.

6. Özvarış Ş B. Topluma dayalı tıp eğitimi. Toplum Hekim Bul 2011; 26: 1-5.

7. Turan-Özdemir S. Tıp eğitimi ve standartlar. Uludağ Üniv Tıp Fak Derg 2005; 31: 133-4.

8. Kalaça, S. İnteraktif çalışma modülü: Eğitim yönlendiricileri için el kitabı. İstanbul: Marmara Üniversitesi Tip Fakültesi Basimevi, 2000.

9. Yeniçeri N, Mevsim V, Özçakar N, Özan S, Güldal D, Başak O. Tıp eğitimi son sınıf öğrencilerinin gelecek meslek yaşamları ile ilgili yaşadıkları anksiyete ile sürekli anksiyetelerinin karşılaştırılması. DEU Tıp Fakültesi Dergisi 2007; 21: 19-5.

10. Çiçek C, Terzi C. Tıpta uzmanlık eğitimi (İzmir ölçekli iki araştırma ve karşılaştırmalı sonuçları). Ankara: Türk Tabipleri Birliği Yayınları, 2006.

http://www.ttb.org.tr/kutuphane/tipta_uzmanlik_egitimi.pdf (Accessed on 22 April 2015)

11. Bozdemir A E, Nesanır N, Arsu G, Batu J, Aslan Ö. Ege ve Dokuz Eylül Üniversitesi tıp fakültelerinde temel tıp bilimlerinde uygulanan uzmanlık eğitiminin eğitici ve eğitilen bakış açısı ile değerlendirilmesi. Mikrobiyol Bült 2006; 40: 333-13.

12. Çiçek C, Terzi C, Solak A, Aksu G, Batu J, Vatansever K. Üniversite hastanelerinde temel bilimler alanında uzmanlık eğitimi: Tıpta uzmanlık öğrencisi bakış açısı ile. Mikrobiyol Bült 2005; 39: 491-10.

13. Tabak R S. Sağlık hizmetlerinde sürekli eğitim ve sürekli mesleki gelişim. Türk Hij Den Biyol Dergisi 2005; 62: 59-6.

14. Bligh J G. Trends in medical education. Eur J Dent Educ 1998; 2: 2-5.doi: 10.1111/j.1600-0579.1998.tb00028.x

15. Özdemir S T. Tıp eğitimi ve yetişkin öğrenmesi. Uludağ Üniv Tip Fak Derg 2003; 29: 25-3.

16. Dimitroff A, Davis WK. Content analysis of research in undergraduate medical education. Acad Med 2006; 71: 60-7. doi: 10.1097/00001888-199601000-00019

17. Regehr G.Trends in medical education research. Acad Med2004;79:939-8.doi: 10.1097/00001888-20041000000008

18. Lifshitz A. Trends in medicaleducation.Gac Med Mex 1997;133: 25-8.

19. Rotgans JI. The themes, institutions and people of medical education research 1988-2010: Content analysis of abstracts from six journals. Adv Health Sci Educ 2012; 17: 515-12.doi: 10.1007/s10459-011-9328-x

20. Büyüköztürk Ş, Kılıç-Çakmak E, Akgün Ö E, Karadeniz Ş, Demirel F. Bilimsel Araştırma Yöntemleri. Ankara: Pegem Akademi, 2012.

21. Karasar N. Bilimsel araştırma yöntemi, Ankara: Nobel Yayınları, 2012.

22. Kıncal RY. (Editor) Bilimsel araştırma yöntemleri. Ankara: Nobel Yayınevi, 2013.

23. Göktaş Y, Küçük S, Aydemir M, et al. Educational technology research trends in Turkey: acontent analysis of the 2000-2009 decade. ESTP 2012; 12:177-12.

24. Lin M, Fisher J, Coates W C et al. Critical appraisal of emergency medicine education research: the best publications of 2012. Acad Emerg Med 2014; 21: 322-11. doi: 10.1111/ acem. 12336.

25. Tosteson D C. New pathways in general medical education. N Engl J Med1990; 322: 234-4.doi: 10.1056/ NEJM199001253220405

26. Roth K, Siemens D R. The status of evidence-based medicine education in urology residency. Can Urol Assoc J 2010; 4: 114-6.

27. Majumder M A. Issues and priorities of medical education research in Asia. Ann Acad Med Singapore 2004; 33:257-6.

28. Doğan N Ö, Günaydın G P, Çevik Y, Otal Y, Levent S, Ç1krıkçı G. Evaluation of knowledge levels of Turkish emergency medicine residents by a theoretical exam. Eurasian J Emerg Med 2013;12: 30-2.doi: 10.5152/jaem.2013.011

29. Yıkılkan H, Türedi Ö, Aypak C, Görpelioğlu S. Ankara ilinde eğitim alan aile hekimliği asistanlarının eğitim gereksinimlerinin değerlendirilmesi. Cumhuriyet Tip Derg 2013; 35: 25-7.doi: 10.7197/1305-0028.1807

30. Rubio D M, Schoenbaum E E, Lee L S, et al. Defining translational research: Implications for training. Acad Med 2010; 85: 470-5.doi: 10.1097/ACM.0b013e3181ccd618

31. Dutta S A. Horizon of medical education research approachin 21st century. Al Ameen J Med Sci 2014; 7: 94-4.

32. BaernsteinA, Liss H K, Carney P A, Elmore J G. Trendsin study methods used in undergraduate medical education research, 1969-2007.JAMA2007; 298: 1038-7.doi: 10.1001/ jama.298.9.1038

33. Tosun C, Yasar M D. Comparisonof problem-based learning studies in scienceeducation in Turkey with the world: Content analysis of research papers. APFSLT 2013; 14: 1-29.www. ied.edu.hk/apfslt/v14_issue2/tosun/index.htm(Accessed on 25August 2015)

34. Kim S. Thefuture of e-learning in medicaleducation: Current trend and future opportunity. J Educ Eval Health Prof 2006; 3:1-7.doi: 10.3352/jeehp.2006.3.3

35. Wiecha J, Heyden R, Sternthal E, Merialdi M. Learning in avirtual world: Experience with using second life for medical education. J Med Internet Res 2010; 12: 1-8.doi: 10.2196/ jmir.1337

36. Akkoç H, Bilgin H M, Daşdağ M M, Çiçek R. Dicle Üniversitesi tıp fakültesinde uygulanan öğretim programının ÇEP ile uyumu ve öğrencilerin yıl sonu notlarındaki değişimler. Dicle Tip Derg 2007; 34: 107-3.

37. Odabaşı O, Sayek İ, Kiper N. Türkiye'de mezuniyet öncesi tıp eğitimi. Turk Pediatri Ars 2010;46: 331-3.doi: 10.4274/ tpa.553

38. Dolmans D H, Gijselaers W H, Moust J H, Grave W S D, Wolfhagen I H, Vleuten C. Trends in research on thetutor in problem-based learning: Conclusions and implications for educational practice and research. Med Teach 2002; 24: 1737. doi: 10.1080/01421590220125277

39. Cohen D L, McCullough L B, Kessel R W, Apostolides A Y, Alden E, Heiderich K J. Informed consent policies governing medical students' inter actions with patients. J Med Educ 1987; 62: 789-9. doi: 10.1097/00001888-198710000-00001 